\title{
Structural effects of meteorite impact on basalt: Evidence from Lonar crater, India
}

\author{
P. Senthil Kumar \\ National Geophysical Research Institute, Hyderabad, India \\ Received 31 January 2005; revised 17 August 2005; accepted 26 August 2005; published 8 December 2005
}

[1] Lonar crater is a simple, bowl-shaped, near-circular impact crater in the $\sim 65 \mathrm{Myr}$ old Deccan Volcanic Province in India. As Lonar crater is a rare terrestrial crater formed entirely in basalt, it provides an excellent opportunity to study the impact deformation in target basalt, which is common on the surfaces of other terrestrial planets and their satellites. The present study aims at documenting the impact deformational structures in the massive basalt well exposed on the upper crater wall, where the basalt shows upward turning of the flow sequence, resulting in a circular deformation pattern. Three fracture systems (radial, concentric, and conical fractures) are exposed on the inner crater wall. On the fracture planes, plumose structures are common. Uplift and tilting of the basalt sequence and formation of the fractures inside the crater are clearly related to the impact event and are different from the preimpact structures such as cooling-related columnar joints and fractures of possible tectonic origin, which are observed outside the crater. Slumping is common throughout the inner wall, and listric faulting displaces the flows in the northeastern inner wall. The impact structures of Lonar crater are broadly similar to those at other simple terrestrial craters in granites and clastic sedimentary rocks and even small-scale experimental craters formed in gabbro targets. As Lonar crater is similar to the strength-controlled laboratory craters, impact parameters could be modeled for this crater, provided maximum depth of fracture formation would be known.

Citation: Kumar, P. S. (2005), Structural effects of meteorite impact on basalt: Evidence from Lonar crater, India, J. Geophys. Res., 110, B12402, doi:10.1029/2005JB003662.

\section{Introduction}

[2] Impact cratering is one of the important geological processes that have modified the surfaces of all planets and satellites of our Solar System [Melosh, 1989]. The impact event produces craters of various sizes and shapes; based on geometry, the craters are classified into simple and complex craters. Simple craters are circular, bowl-shaped depressions with raised rims and quasi-parabolic profiles, whereas complex craters exhibit central structural uplifts, rim synclines and outer concentric zones of normal faulting. An impact-cratering event may be indicated by geomorphology (crater shape) but is recognized on the basis of shock metamorphic signatures in the target rocks [e.g., Melosh, 1989; Koeberl, 1997] and characteristics of the impact melt products [e.g., Dressler and Reimold, 2001] and the ejecta deposits [e.g., Melosh, 1989].

[3] Earth has witnessed impact events throughout its geological history [e.g., Frey, 1980; Glikson, 1993; Montanari et al., 1998]. More than 170 impact structures have been recognized so far, and are listed in the "Earth Impact Database" of Planetary and Space Science Centre, University of New Brunswick, Canada (http://www.unb.ca/passc/ ImpactDatabase/essay.html). An understanding of terrestrial

Copyright 2005 by the American Geophysical Union. 0148-0227/05/2005JB003662\$09.00 impact cratering is important, as it addresses how the outer layer of Earth has been modified due to impacts, and also its effect on the physical, chemical and biological systems. The hazard of near-Earth asteroid or comet impacts on Earth is to be assessed very carefully [e.g., Chapman, 2004]. Impact cratering processes are understood by integrating impact geological information, drilling results, geophysical investigations, laboratory experiments and numerical modeling studies. Of these, numerical modeling has been found to be a powerful tool in understanding the various stages of formation of impact craters [e.g., O'Keefe and Ahrens, 1993, 1999; Melosh and Ivanov, 1999; Wünnemann and Ivanov, 2003; Collins et al., 2004]. Collins et al. [2004] modeled the impact deformation around a $10-\mathrm{km}$-diameter crater, whose target composition was assumed to be granite. They showed that the stresses, strains, and strain rates are all highest near the impact site and decrease with radial distance. However, as pointed out by these authors, it is very important to validate numerical models based on the observational evidence, especially using the quantitative analysis of damage and deformation in the target surrounding a natural impact crater. Therefore structural geological studies, which include identification of various impact deformational features, their geometries, kinematics, and quantification of strain, are required for modeling the impact cratering processes. 


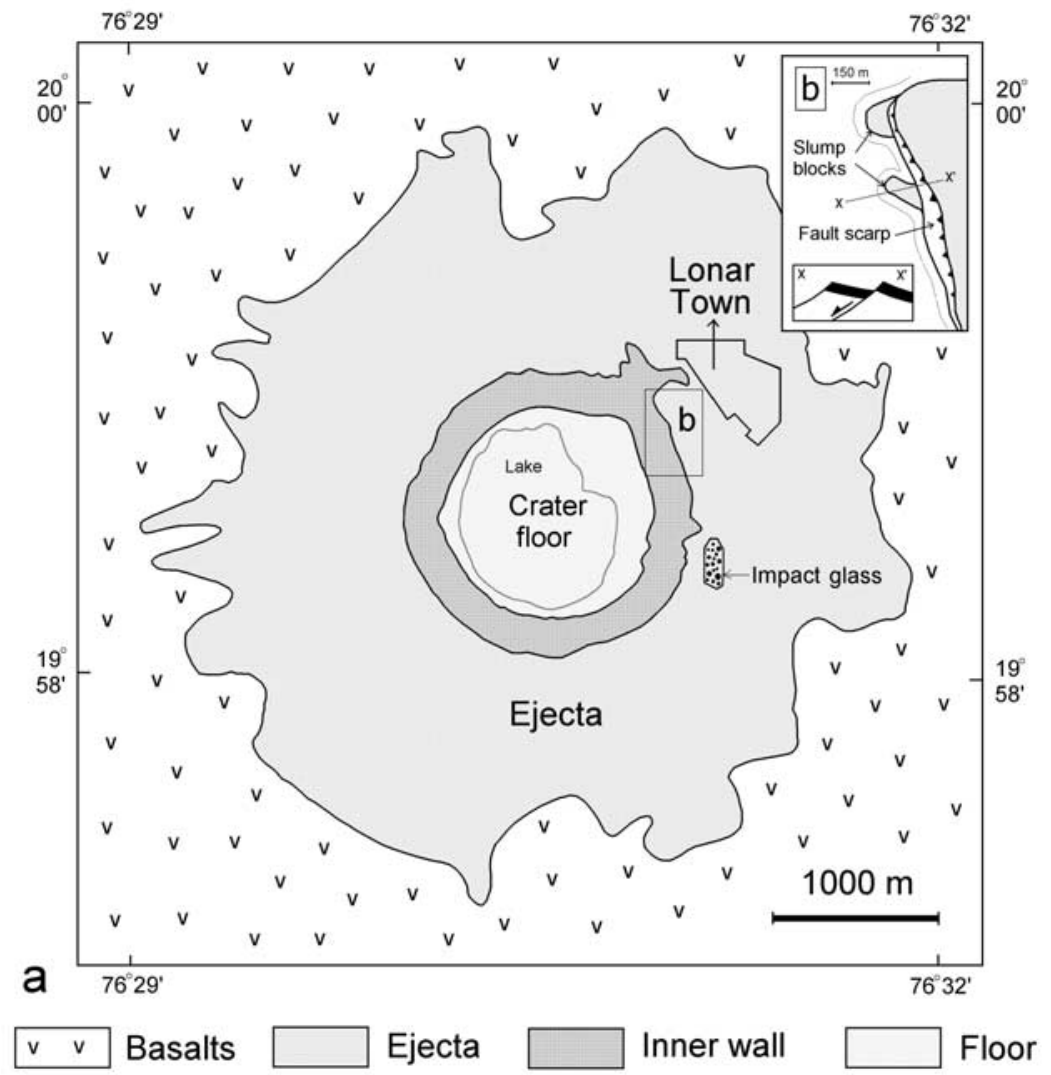

Figure 1. (a) Geological sketch map of Lonar crater. Boundary of the ejecta is drawn on the basis of the work by Ghosh [2003]. A massive basalt flow is well exposed on the upper crater wall, and the underlying flows are covered by basalt debris, soil, and vegetation. Impact melt fragments and spherules are found in the clayey alteration products of the ejecta materials, and one such occurrence is shown in the map. (b) A sketch map of normal faulting in the northeastern part of the inner wall.

[4] Although impact structures have been studied extensively on Earth [e.g., Ackermann et al., 1975; Grieve and Robertson, 1976; Brandt and Reimold, 1995; Dressler and Sharpton, 1997; Reimold et al., 1998a; Bjørnerud, 1998; Christeson et al., 2001; Lemieux et al., 2003; Sagy et al., 2004], there is no detailed study available on the structural effects of meteorite impact on basalt, forming a simple impact crater, like Lonar (Figure 1). As Lonar crater is one of the two known rare natural craters formed entirely in basalt, the study of its structural geology would throw light on the impact deformation processes that takes place on terrestrial planets and their satellites. Therefore, in the present study, the structural geology of basalts exposed both inside and outside Lonar crater is documented, in order to resolve the precratering, syncratering, and postcratering structures.

\section{Geology}

[5] Lonar crater was formed in Deccan basalts (Figure 1), at $19^{\circ} 58^{\prime} \mathrm{N}, 76^{\circ} 31^{\prime} \mathrm{E}$, near Lonar village in Buldhana district of Maharashtra State in India. The $\sim 65$ Myr old Deccan basalts overlie the Precambrian rock formations and Paleozoic-Mesozoic sedimentary rocks of the southern Indian Shield. The regional geology of the Deccan basalts has been reviewed by Subbarao [1999], and the geological setting of Lonar crater was discussed by Fudali et al.
[1980]. Lonar crater is a simple, bowl-shaped crater with a rim-to-rim diameter of $\sim 1.8 \mathrm{~km}$, and a rim-to-floor depth of $\sim 150 \mathrm{~m}$ (apparent depth). A continuous blanket of ejecta extends outward to a distance of $\sim 1350 \mathrm{~m}$ from the rim crest, and contains basalt fragments of various sizes and shapes, clays, and glassy impact melt fragments and spherules at a number of places. The slope of the ejecta blanket is $2^{\circ}-6^{\circ}$ away from the crater. Maximum elevation of the crater rim is 590-600 $\mathrm{m}$ above mean sea level, and the elevation of the central crater floor is $\sim 470 \mathrm{~m}$. A shallow alkaline lake occupies the crater floor. Drilling carried out in the crater floor revealed $\mathrm{a} \sim 100 \mathrm{~m}$ thick lensoidal deposit of crater sediments underlain by intensely fractured basaltic rocks [Fredriksson et al., 1973]. The depth of the true crater floor may be $>400 \mathrm{~m}$ below the rim crest, as calculated from the drilling results. Basalt breccia recovered in the drill cores shows evidence for postimpact hydrothermal alteration [e.g., Hagerty and Newsom, 2003].

[6] Five individual flows of massive, vesicular and amygdaloidal basalts are exposed on the inner wall. The basalts are quartz-normative tholeiites of high total iron and $\mathrm{CaO}$, and lower $\mathrm{Al}_{2} \mathrm{O}_{3}$ and $\mathrm{MgO}$, similar to the compositions of basaltic Martian meteorites [Hagerty and Newsom, 2003]. Although Lonar crater was initially thought to be volcanic in origin, La Fond and Dietz [1964] demonstrated its impact origin based on geomorphology and documenting shock effects [see also Nayak, 1972; Fredriksson et al., 


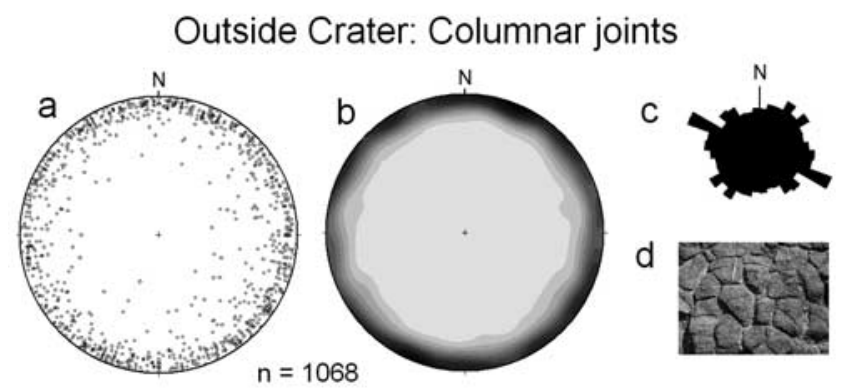

Outside Crater: Fractures

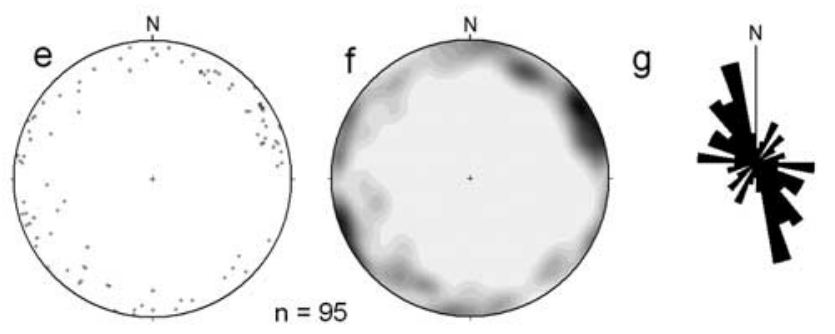

Figure 2. Preimpact structures observed in massive basalt outside of Lonar crater. (a) Equal-area plots of poles to the orientation of columnar joints. (b) Pole density contours of columnar joint orientations, (c) Length-weighted rose diagram for columnar joint orientations. (d) Photograph of columnar joints; length of the pen is $\sim 10 \mathrm{~cm}$. (e) Equal-area plots of poles to the orientation of tectonic fractures, which were mapped $\sim 15 \mathrm{~km}$ SSE of Lonar. (f) Pole density contours of tectonic fracture orientations. (g) Lengthweighted rose diagram for the tectonic fracture orientations. RockWorks-2004 software was used to generate the equalarea plots using the Schmidt net and the length-weighted rose diagrams.

1973; Fudali et al., 1980; Rao and Bhalla, 1984; Ghosh and Bhaduri, 2003].

\section{Preimpact Structures}

[7] Structural geological mapping of an impact crater and the surrounding regions allows comparison of the nature of the target rocks before and after an impact event. Rock exposures outside Lonar crater are very limited. Most of them are covered by soils and weathering products. Only two or three lava flows could be observed. A massive basalt flow overlies the other flows, which are composed of strongly altered vesicular and amygdaloidal basalts. In general, the flows are oriented horizontally, and only at a few places do they show a slight upwarping or downwarping. The most important feature of the massive flow is the presence of coolingrelated [Budkewitsch and Robin, 1994; Grossenbacher and McDuffie, 1995] columnar joints or colonnade (Figure 2d). The columns show polygonal outlines on the surface and most have hexagonal geometry. Column diameter varies from a few $\mathrm{cm}$ to $>1 \mathrm{~m}$. Strike and dip of the joints have been measured in a quarry on the eastern slope of a small hillock located about $2 \mathrm{~km}$ ESE of the crater. The data are presented in Figures $2 \mathrm{a}, 2 \mathrm{~b}$, and $2 \mathrm{c}$, which show that the columnar joints dip steeply and have multiple orientations, resulting in circular pole density contours (Figure 2b). The deeply altered underlying flows are rich in laterites and clays, in which columnar joints are absent.

[8] Massive basalt without columnar joints is also present but is comparatively rarer. It shows fractures, which are related to tectonic deformation (Figures 2e, $2 \mathrm{f}$, and $2 \mathrm{~g}$ ). Most of them are subvertical and are oriented in NW-SE to NNW-SSE directions, and a few other fractures strike in NE-SW direction. Some fractures occur as conjugate pairs. Although the exact origin of these fractures is unknown as of now, they are broadly similar to the major fracture systems found in other parts of the Deccan Volcanic Province [e.g., Widdowson and Mitchell, 1999].

[9] Thickness and nature of the basaltic sequence in Lonar is unknown. Drilling studies at the 1993 Latur earthquake site, which is located $\sim 150 \mathrm{~km}$ south of Lonar, suggested that the thickness of the basalt sequence is $\sim 350 \mathrm{~m}$, and is underlain by Archaean granites and gneisses [Gupta et al., 1999], which are the common rock types in the southern Indian Shield. In Lonar, the basalt sequence may be thicker, as several studies have indicated a northward increase of its thickness [e.g., Mitchell and Widdowson, 1991]. More geophysical investigations and drilling studies are required at Lonar and in the surrounding areas to delineate the entire basaltic sequence and the underlying basement granites and gneisses. Determining the mechanical properties of these rocks is also essential to assess the preimpact and synimpact target conditions, which are important for understanding how these rocks behaved during the impact, and the nature of shock wave propagation through this medium. The presence of columnar joints and tectonic fractures in massive basalts and deep weathering in the other flows would indicate a significant reduction of their strength. Therefore the mechanical behavior of these rocks should be different from the fracture- and alteration-free massive basalts.

\section{Impact Structures}

[10] Inside Lonar crater, an approximately 30-m-thick massive basalt flow is well exposed a few meters below the crater rim. This is the only flow exposed more or less continuously, whereas the underlying flows are largely covered by basalt debris (talus), soil and vegetation. Hence structural mapping was restricted to this massive flow. It involved documentation of the attitude of lava flow, various fracture systems, faults and slump units. The inner crater wall was divided into twelve angular zones with $30^{\circ}$ intervals. The respective attitudes of this lava flow in these 12 zones are presented in Figure 3. The upper flow strikes parallel to the rim crest and dips gently outward at low angles. Well-defined tightly spaced subplanar fractures are developed parallel to the lava flow throughout the crater wall. These fractures are absent in the massive basalt outside the crater. It appears likely that these fractures were formed as a result of the impact. Dip of the flow-parallel fractures varies between $5^{\circ}$ and $35^{\circ}$, and in the slump units (Figure 1b), it reaches $50^{\circ}-70^{\circ}$ (see zone 2 in Figure 3). Mean dip of these fractures in 


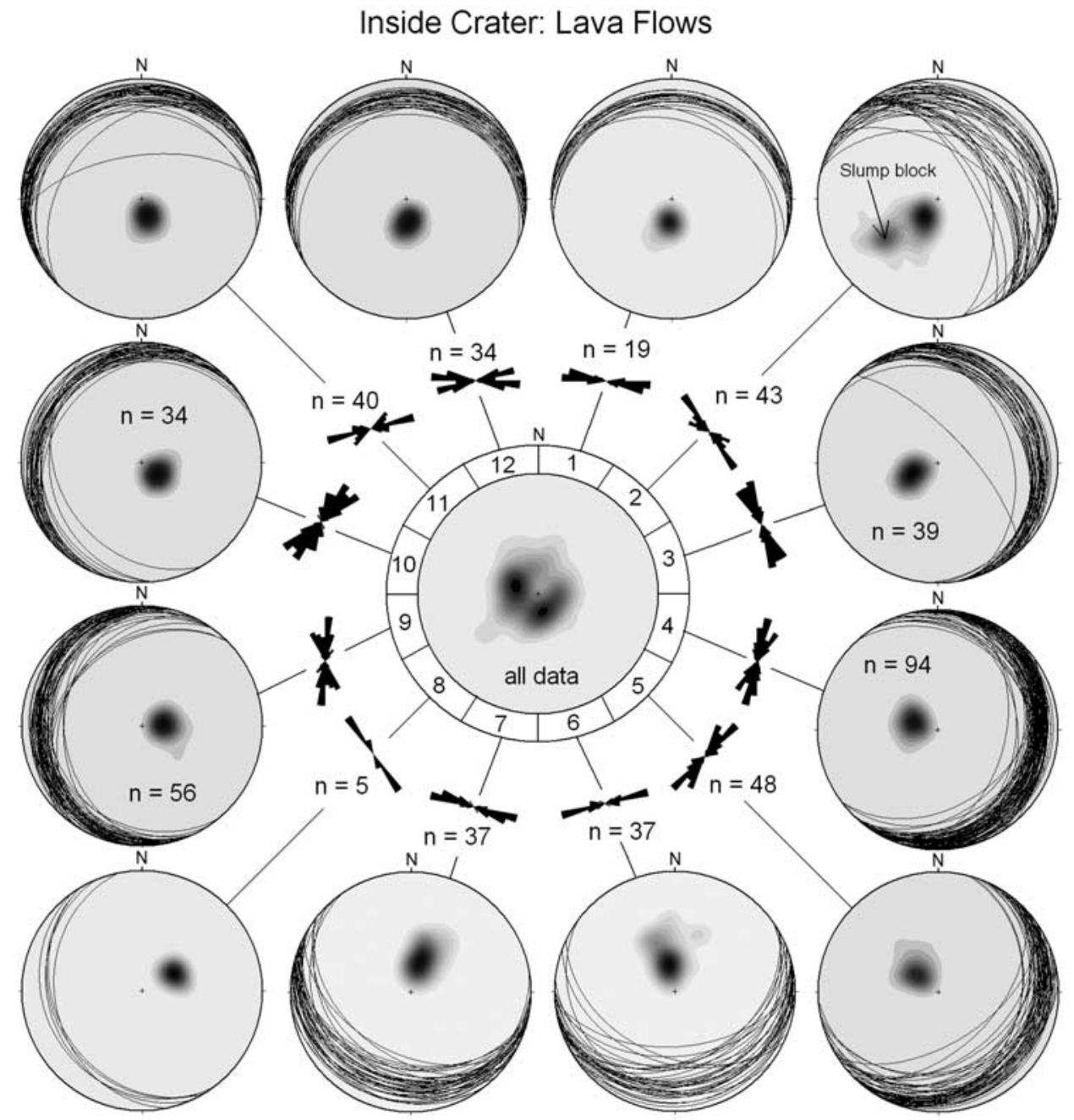

Figure 3. Equal-area plots of strikes and dips of the flow-parallel fractures in the basalt flow in the 12 zones of the upper crater wall. The data are shown as great circles and pole density contours. Lengthweighted rose diagrams show the variation in the strikes of the lava flow throughout the upper crater wall.

the 12 zones varies from $11^{\circ}$ (in zone 10 ) to $31^{\circ}$ (in zone 2 ). Figure 3 clearly indicates the amount of outward dip of the lava flow in the crater wall is more or less similar, averaging at $\sim 20^{\circ}$. When all the data are plotted into the Schmidt net (equal-area projection), they show concentric pole density contours, supporting the strong circular deformation pattern in the lava flow around the crater (Figure 3). The data document the amount of rim uplift from the impact event, which would be useful for modeling the impact cratering event.

[11] Figures 4, 5, and 6 show the geometries of the various fracture systems, which are radial, concentric, and conical fractures exposed on the upper crater wall, respectively. The radial fractures have more or less steep dips and strikes that are approximately perpendicular to the crater rim, although some of them are oriented obliquely (Figure 4). The radial fractures occur as single, conjugate pairs, and branching types. Most of them are straight to curvilinear. The concentric fractures strike more or less parallel to the crater rim and dip toward the crater floor (Figure 5). Amount of dip of these fractures is also highly variable. The conical fractures are similar to the concentric fractures in their strikes but dip away from the crater center, and have highly variable amount of dip (Figure 6). All these fracture planes preserve plumose structures.

[12] Faulting and slumping are common on the inner slope. On the northeastern slope, normal faulting has been observed (Figure 1b). In the footwall the dip of the flow is $\sim 20^{\circ}$, whereas in the hanging wall it is steeper $\left(50^{\circ}-70^{\circ}\right)$ (see zone 2 in Figure 3). These structures appear to have formed during the crater modification stage. It is possible that the faulting and slumping are structurally controlled by the concentric fractures. Although this study clearly shows the structural effect of the meteorite impact (Figure 7; also see the auxiliary material), the extent of impact deformation cannot be assessed with the present data. ${ }^{1}$ The drilling results indicated the presence of weak to strongly deformed

${ }^{1}$ Auxiliary material is available at $\mathrm{ftp} / / \mathrm{ftp}$.agu.org/apend/jb/ 2005JB003662. 


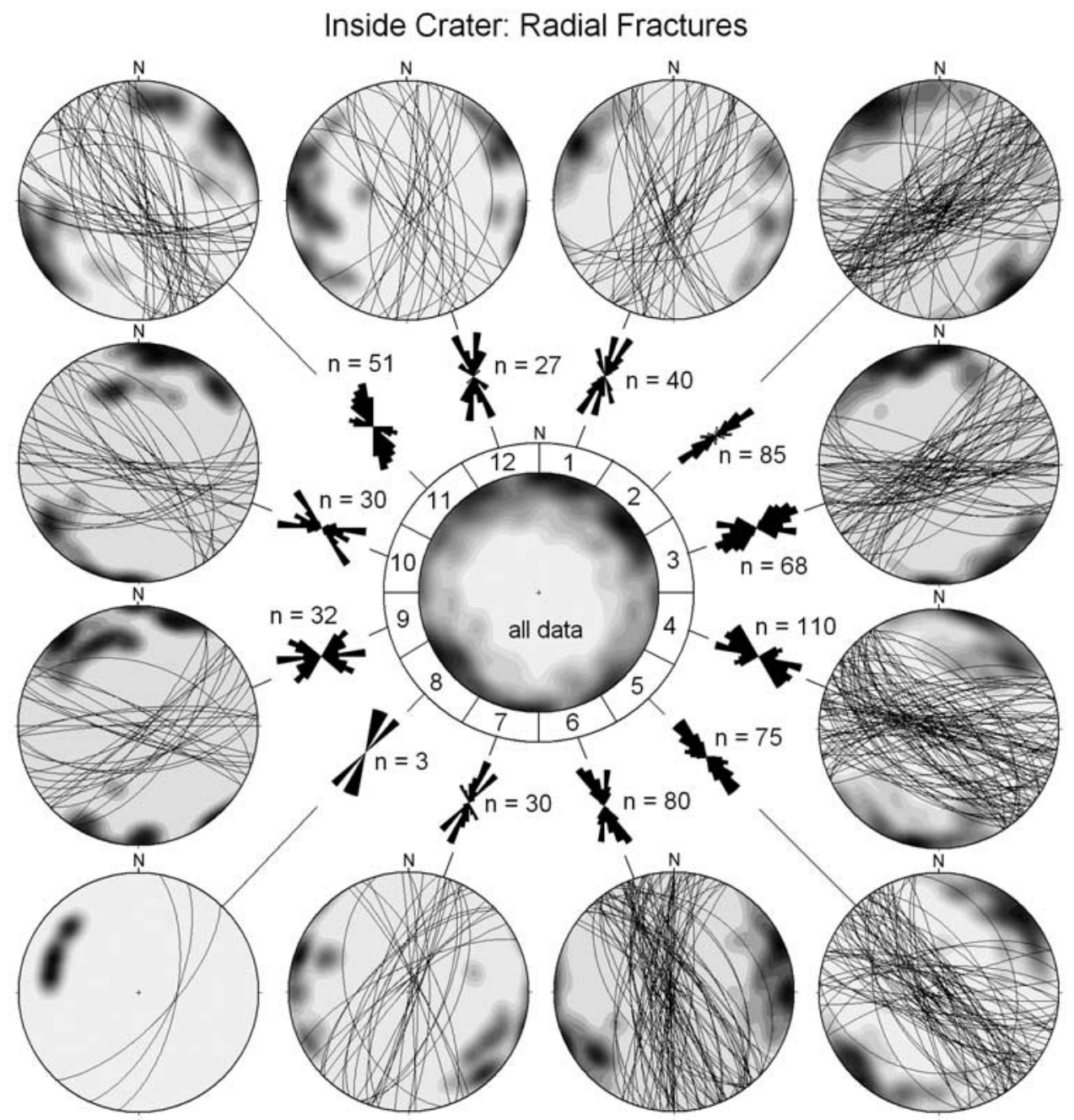

Figure 4. Equal-area plots of strikes and dips of the radial fractures in the massive basalt flow in the upper crater wall. The data are shown as great circles and pole density contours for the 12 crater rim zones. Length-weighted rose diagrams show the variation in the strikes of radial fractures along the entire extent of the upper crater wall. 


\section{Inside Crater: Concentric Fractures}

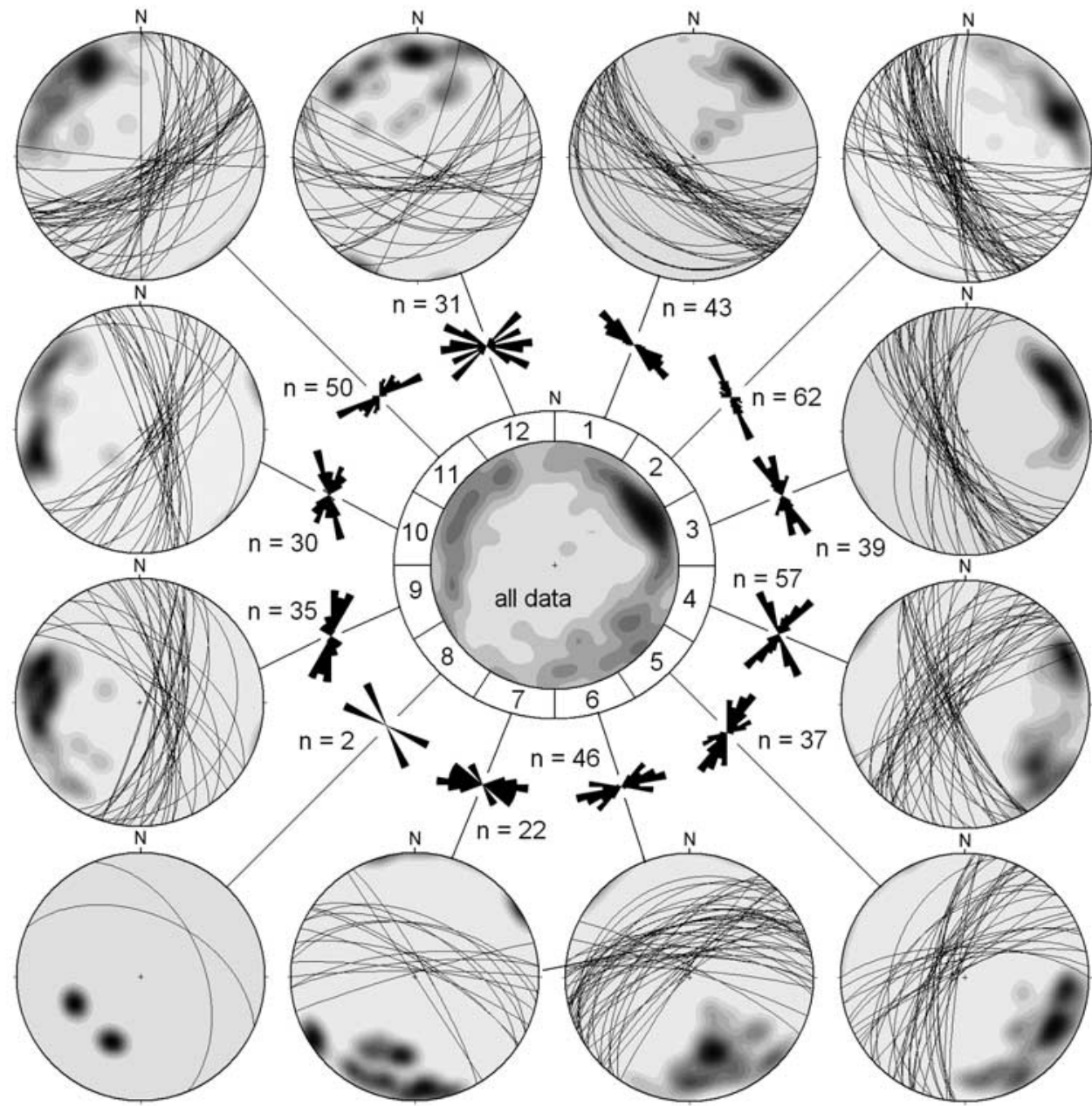

Figure 5. Equal-area plots of strikes and dips of the concentric fractures in the massive basalt flow in the upper crater wall. The data are shown as great circles and pole density contours for the 12 crater rim zones. Length-weighted rose diagrams show the variation in the strikes of the concentric fractures along the entire extent of the upper crater wall. 
Inside Crater: Conical Fractures

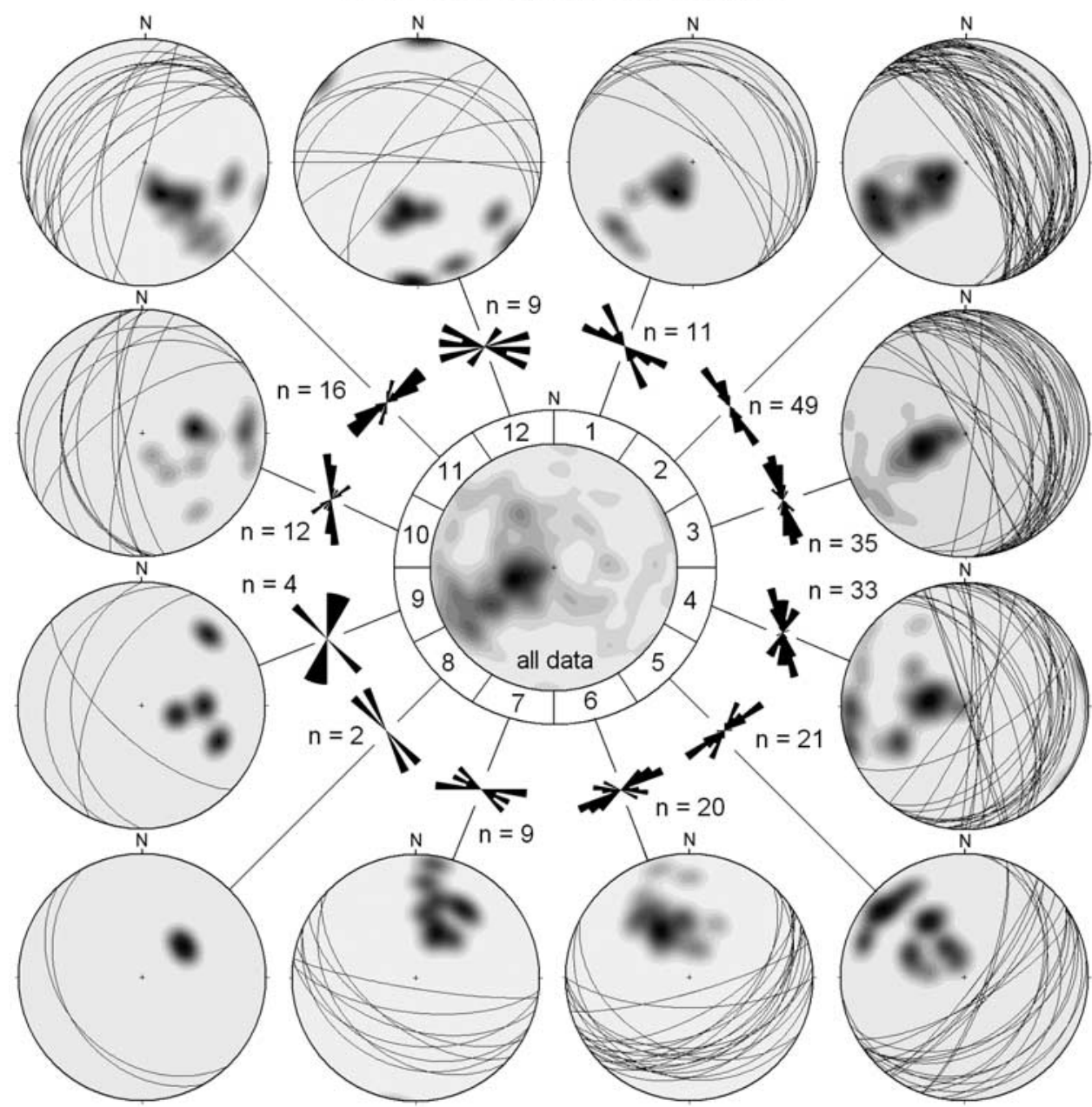

Figure 6. Equal-area plots of strikes and dips of the conical fractures in the massive basalt flow in the upper crater wall. The data are shown as great circles and pole density contours for the 12 crater rim zones. Length-weighted rose diagrams show the variation in the strikes of the conical fractures throughout the upper crater wall. 

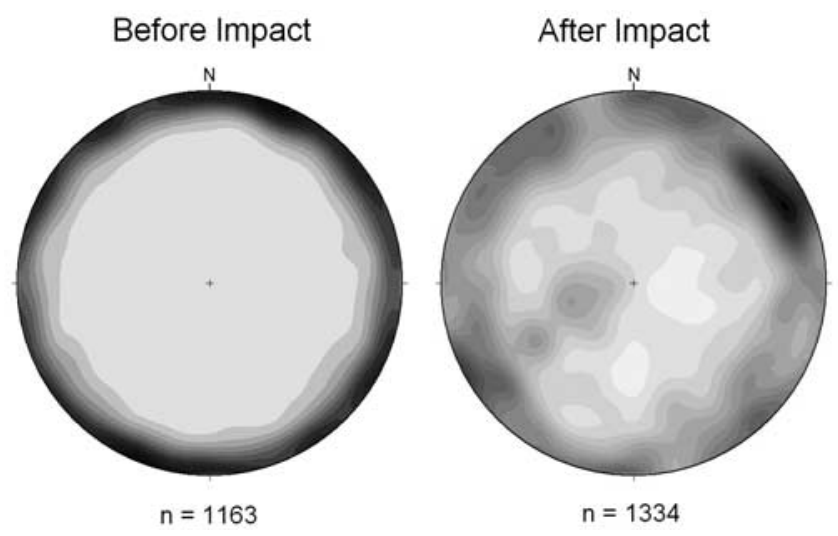

Figure 7. Distinction between the preimpact and impact fractures. (left) Preimpact structures in the basalt outside the crater rim: orientations of the columnar joints and tectonic fractures are shown together as pole density contours. See also Figure 2. (right) Postimpact structures in the inner crater wall: orientations of the radial, concentric, and conical fractures are shown together as pole density contours. See also Figures 4, 5, and 6. Note that the lava flows are generally subhorizontal outside Lonar crater, whereas they show uplift and tilting throughout the crater rim, resulting in a circular deformation pattern. See Figure 3. See the auxiliary material for the strikes and dips data of preimpact and impact structures.

basaltic breccia and fine sediments beneath the present-day crater floor [Fredriksson et al., 1973], but the nature of fracture patterns, and the attitude of lava flows beneath the true crater floor are still unknown. Hence high-resolution seismic imaging and deep drilling studies are required to delineate the extent of impact deformation beneath Lonar crater.

\section{Comparison: Natural Simple Craters}

[13] Comparison of the simple impact craters is essential to recognize whether any deformation features are common to all of them. Brandt and Reimold [1995] have summarized some of the common deformational features among a few simple craters, whose targets were composed of granites and clastic sedimentary rocks. It is interesting to note that the upward turning of basalt flows in the upper crater wall of Lonar crater (Figures 3 and 8b) is similar to the impact deformation of target strata at other simple craters, for example, Meteor crater in Arizona [Shoemaker, 1960], Odessa crater [Shoemaker and Eggleton, 1961], Tswaing crater [Brandt and Reimold, 1995], Kalkkop crater [Reimold et al., 1998b], and Aouelloul crater [Koeberl et al., 1998]. Lonar crater consistently shows upward turning of the flow sequence throughout the middle to upper crater wall (Figures 3 and $8 \mathrm{~b}$ ), but in other craters, inward dipping of rock formations has been observed in the lower parts of the inner crater wall [e.g., Brandt and Reimold, 1995; Reimold et al., 1998b]. It is not clear whether Lonar crater, too, would have such inward dips of basalt flows in the lower part of the crater wall. Other structures that Lonar and other craters have in common are the radial, concentric and conical fracture systems (Figures 4, 5, 6, 8b, and 8c), as well as the inward dipping normal faults that give rise to slumping (Figure 1b). At Lonar crater, no folds have been observed, which are common in the midsection of walls of other craters [e.g., Brandt and Reimold, 1995], and inward and outward (with reference to the crater wall) propagating thrusts are also lacking. Although a common cratering mechanism controls the formation of all the above craters, the nature of the target rocks (e.g., composition, competence, heterogeneity in the distribution of preimpact structures and mechanical properties) clearly play a major role in the observed difference in the deformation features between them.

\section{Comparison: Experimental Craters}

[14] On Earth, formation of bowl-shaped, simple craters (up to $3-5 \mathrm{~km}$ diameter) appears to be strength controlled. Simple craters form when the transient crater is more or less stable in the gravity field. Strength of the target material can resist the gravitational forces acting against the crater rim, and therefore the shape of the transient crater is generally retained. The strongly damaged rocks in the crater wall slide down the crater rim, forming a lensoidal breccia deposit in the crater floor, together with fall-back ejecta. Beneath simple craters, the maximum depth of fracturing is approximately proportional to the crater diameter [Ahrens et al., 2002]. Shockinduced fracturing beneath experimentally produced small-scale craters appears to be controlled by the same physical processes as the fracturing beneath strengthcontrolled, simple natural craters [Ahrens et al., 2002]. Hence the structures in Lonar crater can be compared with the results of laboratory impact experiments by Polanskey and Ahrens [1990], who used San Marcos gabbro as target (Figure 8a). Figure 8a shows a vertical section through the gabbro target revealing the sets of radial and concentric fractures below a zone of nearsurface fractures or conical fractures, according to Ahrens et al. [2002]. The location of these fractures coincides with the theoretical near-surface zone predicted by a spallation model [Polanskey and Ahrens, 1990] (Figure 8a). Above this zone, in most of the experiments, the target is visibly unfractured. A thin band of fractures, called spall fractures, starting at the top of the crater wall and arcing down into the target, is also observed. As a plan view of this experimental crater is not available, comparison of fractures beneath the experimental crater with those in Lonar crater is difficult. This is mainly because, the radial fractures seen on the plan view of the Lonar crater (Figure 4) do not correspond with the radial fractures seen on the vertical section of the experimental crater (Figure 8a). However, the concentric and conical fractures observable on the vertical section of Lonar crater (Figure $8 \mathrm{~b}$ ) are broadly similar to the concentric fractures and conical or radial fractures observed on the vertical section of the experimental crater (Figure 8a). However, much more detail is still required regarding the fracture networks in plan view of the experimental crater as well as in the middle to lower inner crater wall of Lonar crater.

[15] Ahrens et al. [2002] found that the maximum depth of fracturing beneath small-scale natural and experimental 

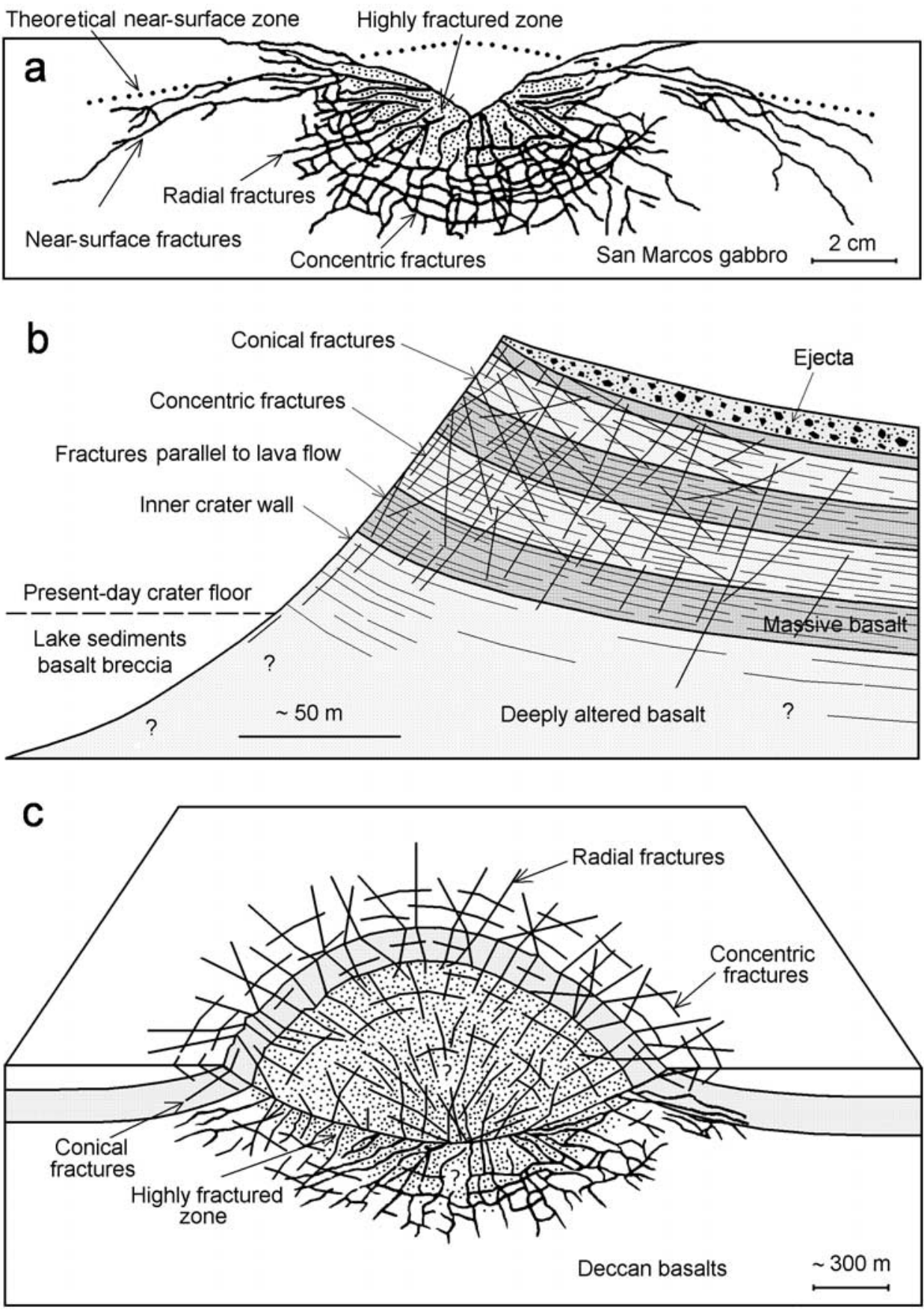

Figure 8. (a) Schematic fracture network beneath an experimentally produced crater in San Marcos gabbro [after Polanskey and Ahrens, 1990]. Reprinted with permission from Elsevier. (b) A schematic cross section of the northern rim of Lonar crater. The various fracture systems are shown on the basis of observations made along the entire middle to upper crater wall. (c) A schematic 3-D picture of deformation at Lonar crater.

craters is related to impactor energy and velocity. This was inferred from a small-scale experimental crater by Polanskey and Ahrens [1990] and from the observations at Meteor Crater in Arizona [Xia and Ahrens, 2001], where the maximum depth of fracturing is $\sim 1 \mathrm{~km}$ [Ackermann et al., 1975]. Hence determination of the maximum extent of impact-induced fracturing constrains the impactor velocity. Similar estimates could be made for Lonar crater when the underlying fracture systems are mapped using high-resolution seismic studies [e.g., Ackermann et al., 1975].

\section{Summary}

[16] The present study documents the various impactrelated deformational features in basalt, the target of meteorite impact in Lonar. Rim uplift and tilting, the 
development of radial, concentric and conical fractures, and faulting of the crater wall and slumping, are the main impact deformational features, which are different from the preimpact structures such as cooling-related columnar joints and tectonically derived fractures in basalts outside the crater. The impact deformation structures of Lonar are essentially similar to those at other terrestrial craters emplaced in granites and clastic sedimentary rocks. As Lonar crater is also broadly similar to the strengthcontrolled laboratory craters, the impact parameters can be modeled for this crater once the maximum depth of impact fracturing will have been determined. As Lonar crater is a rare meteorite impact structure formed entirely in basalt, it is helpful for the understanding of similar craters on other terrestrial planets and satellites. In addition, the structural geological data presented in this study will be useful in modeling the impact cratering event.

[17] Acknowledgments. The author sincerely thanks the reviewers (Sarah. T. Stewart-Mukhopadhyay and Wolf U. Reimold) and the Associate Editor for very helpful comments. Wolf U. Reimold helped very generously in improving the revised manuscript. Sarah. T. StewartMukhopadhyay provided valuable information on the experimental craters. H. J. Melosh is thanked for e-mail discussions. The author is grateful to D. Mukhopadhyay for suggesting many improvements to an earlier version of the manuscript as well as to the revised manuscript. Thanks are owed to T. Seshunarayana and S. S. Rai for supporting the field mapping and V. P. Dimri, Director, NGRI, for the encouragement and for granting permission to publish this paper.

\section{References}

Ackermann, H. D., R. H. Godson, and J. S. Watkins (1975), A seismic refraction technique used for subsurface investigations at Meteor crater, Arizona, J. Geophys. Res., 80, 765-775.

Ahrens, T. J., K. Xia, and D. Coker (2002), Depth of cracking beneath impact craters: New constraint for impact velocity, in Shock Compression of Condensed Matter, edited by M. D. Furnish, N. N. Thadhani, and Y. Horie, pp. 1393 -1396, Am. Inst. of Phys., New York.

Bjørnerud, M. G. (1998), Superimposed deformation in seconds: Breccias from the impact structure at Kentland, Indiana (USA), Tectonophysics, 290, 259-269.

Brandt, D., and W. U. Reimold (1995), The geology of the Pretoria Saltpan impact structure and the surrounding area, S. Afr. J. Geol., 98, 287-303.

Budkewitsch, P., and P.-Y. Robin (1994), Modeling the evolution of columnar joints, J. Volcanol. Geotherm. Res., 59, 219-239.

Chapman, C. R. (2004), The hazard of near-Earth asteroid impacts on Earth, Earth Planet. Sci. Lett., 222, 1-15.

Christeson, G. L., Y. Nakamura, R. T. Buffler, J. Morgan, and M. Warner (2001), Deep crustal structure of the Chicxulub impact crater, J. Geophys. Res., 106, 21,751-21,769.

Collins, G. S., H. J. Melosh, and B. A. Ivanov (2004), Modeling damage and deformation in impact simulations, Meteorit. Planet. Sci., 39, 217-231.

Dressler, B. O., and W. U. Reimold (2001), Terrestrial impact melt rocks and glasses, Earth Sci. Rev., 56, 205-284.

Dressler, B. O., and V. L. Sharpton (1997), Breccia formation at a complex impact crater, Slate Islands, Lake Superior, Ontario, Canada, Tectonophysics, 275, 285-311.

Fredriksson, K., A. Dube, D. J. Milton, and M. S. Balasundaram (1973), Lonar Lake, India: An impact crater in basalt, Science, 180, 862-864.

Frey, H. (1980), Crustal evolution of the early Earth: The role of major impacts, Precambrian Res., 10, 195-216.

Fudali, R. F., D. J. Milton, K. Fredriksson, and A. Dube (1980), Morphology of Lonar Crater, India: Comparisons and implications, Moon Planets, $23,493-515$.

Ghosh, S. (2003), Is Lonar astrobleme an example of cometary impact?, Indian Miner., 57, 105-114.

Ghosh, S., and S. K. Bhaduri (2003), Petrography and petrochemistry of impact melts from Lonar crater, Buldhana district, Maharashtra, Indian Miner., 57, 1-26.

Glikson, A. Y. (1993), Asteroids and early Precambrian crustal evolution, Earth Sci. Rev., 35, 285-319.

Grieve, R. A. F., and P. B. Robertson (1976), Variation in shock deformation at the Slate islands impact structure, Lake Superior, Canada, Contrib. Mineral. Petrol., 58, 37-49.
Grossenbacher, K. A., and S. M. McDuffie (1995), Conductive cooling of lava: Columnar joint diameter and stria width as functions of cooling rate and thermal gradient, J. Volcanol. Geotherm. Res., 69, 95-103.

Gupta, H. K., R. U. M. Rao, R. Srinivasan, G. V. Rao, G. K. Reddy, K. K. Dwivedy, D. C. Banerjee, R. Mohanty, and Y. R. Satyasaradhi (1999), Anatomy of surface rupture zones of two stable continental region earthquakes, 1967 Koyna and 1993 Latur, India, Geophys. Res. Lett., 26, $1985-1988$

Hagerty, J. J., and H. E. Newsom (2003), Hydrothermal alteration at the Lonar Lake impact structure, India: Implications for impact cratering on Mars, Meteorit. Planet. Sci., 38, 365-381.

Koeberl, C. (1997), Impact cratering: The mineralogical and geochemical evidence, in Ames Structure in Northwest Oklahoma and Similar Features: Origin and Petroleum Production, edited by K. S. Johnson and B. A. Campbell, Circ. Okla. Geol. Surv., 100, 30-54.

Koeberl, C., W. U. Reimold, and S. B. Shirey (1998), The Aouelloul crater, Mauritania: On the problem of confirming the impact origin of a small crater, Meteorit. Planet. Sci., 33, 513-517.

La Fond, E. C., and R. S. Dietz (1964), Lonar crater, India: A meteorite crater?, Meteoritics, 2, 111-116.

Lemieux, Y., A. Tremblay, and D. Lavoie (2003), Structural analysis of supracrustal faults in the Charlevoix area, Quebec: Relation to impact cratering and the St-Laurent fault system, Can. J. Earth Sci., 40, $221-$ 235.

Melosh, H. J. (1989), Impact Cratering: A Geologic Process, 245 pp., Oxford Univ. Press, New York.

Melosh, H. J., and B. A. Ivanov (1999), Impact crater collapse, Annu. Rev. Earth Planet. Sci., 27, 385-415.

Mitchell, C., and M. Widdowson (1991), A geological map of the southern Deccan Traps, India and its structural implications, J. Geol. Soc. London, 148, 495-505.

Montanari, A., A. C. Bagatin, and P. Farinella (1998), Earth cratering record and impact energy flux in the last $150 \mathrm{Ma}$, Planet. Space Sci., 46, $271-$ 281

Nayak, V. K. (1972), Glassy objects (impact glass?): A possible new evidence for meteoritic origin of the Lonar crater, Maharashtra State, India, Earth Planet Sci. Lett., 14, $1-6$.

O'Keefe, J. D., and T. J. Ahrens (1993), Planetary cratering mechanics, J. Geophys. Res., 98, 17,011-17,028.

O'Keefe, J. D., and T. J. Ahrens (1999), Complex craters: Relationship of stratigraphy and rings to impact conditions, J. Geophys. Res., 104, 27,091-27,104.

Polanskey, C. A., and T. J. Ahrens (1990), Impact spallation experiments: Fracture patterns and spall velocities, Icarus, 87, 140-155.

Rao, G. V. S. P., and M. S. Bhalla (1984), Lonar Lake: Palaeomagnetic evidence of shock origin, Geophys. J. R. Astron. Soc., 77, 847-862.

Reimold, W. U., D. Brandt, and C. Koeberl (1998a), Detailed structural analysis of the rim of a large, complex crater: Bosumtwi crater, Ghana, Geology, 26, 543-546.

Reimold, W. U., C. Koeberl, and J. S. V. Reddering (1998b), The 1992 drill core from the Kalkkop impact crater, Eastern Cape Province, South Africa: Stratigraphy, petrography, geochemistry and age, J. Afr. Earth Sci., 26, 573-592.

Sagy, A., J. Fineberg, and Z. Reches (2004), Shatter cones: Branched, rapid fractures formed by shock impact, J. Geophys. Res., 109, B10209, doi:10.1029/2004JB003016.

Shoemaker, E. M. (1960), Penetration mechanics of high velocity meteorites, illustrated by Meteor crater, Arizona, in 21st International Geological Congress, pp. 418-434, Int. Union of Geol. Sci., Trondheim, Norway.

Shoemaker, E. M., and R. E. Eggleton (1961), Terrestrial features of impact origin, in Proceedings of the Geophysical Laboratory/Lawrence Radiation Cratering Symposium, edited by M. D. Milo, pp. A1 - A27, Lawrence Berkeley Natl. Lab., Berkeley, Calif.

Subbarao, K. V. (Ed.) (1999), Deccan Volcanic Province, Mem. Geol. Soc. India, 43, $947 \mathrm{pp}$.

Widdowson, M., and C. Mitchell (1999), Large-scale stratigraphical, structural and geomorphological constraints for earthquakes in the southern Deccan Traps, India: The case for denudationally-driven seismicity, in Deccan Volcanic Province, edited by K. V. Subbarao, Mem. Geol. Soc. India , 43, 425-452.

Wünnemann, K., and B. A. Ivanov (2003), Numerical modeling of the impact crater-depth dependence in an acoustically fluidized target, Planet. Space Sci., 51, 831-845.

Xia, K., and T. J. Ahrens (2001), Impact induced damage beneath craters, Geophys. Res. Lett., 28, 3525-3528.

P. S. Kumar, National Geophysical Research Institute, Post Bag 724, Uppal Road, Hyderabad 500 007, India. (senthilngri@yahoo.com) 